\title{
Neuroimaging of retinal nerve fiber layer in AD using optical coherence tomography
}

Figure $\quad$ Normal retinal NFL (A) and moderate AD NFL (B)
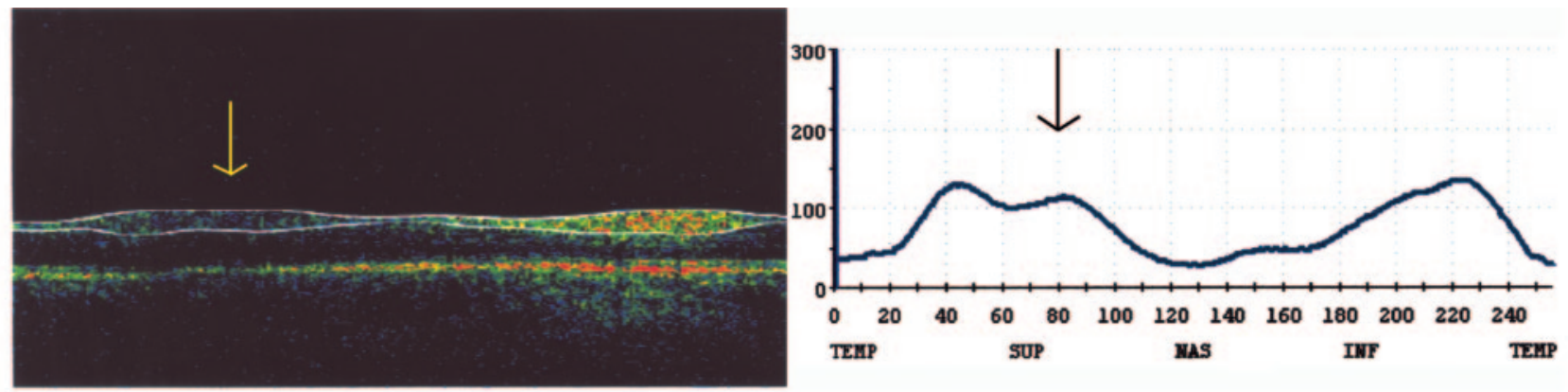

B
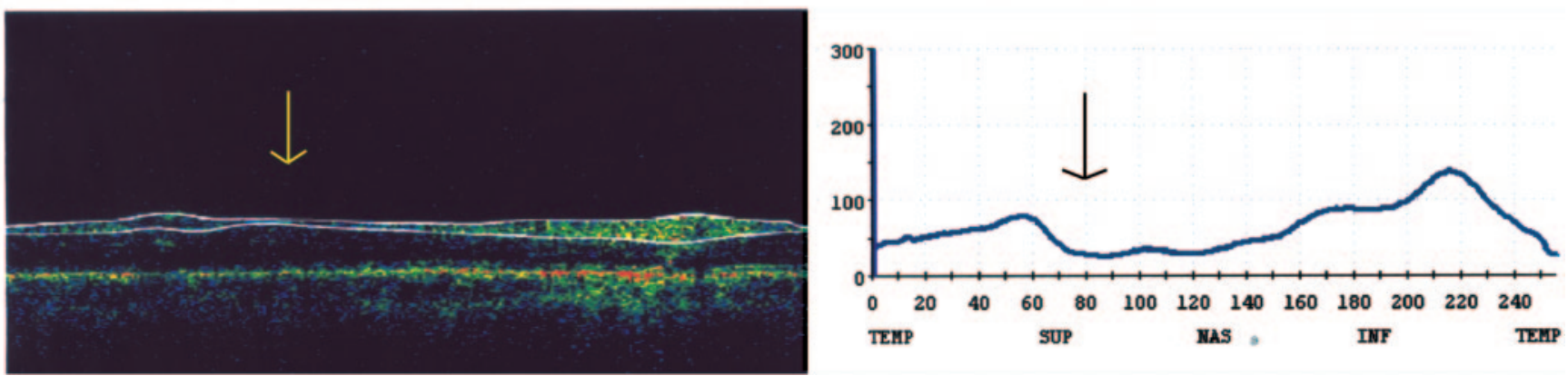

On the left are optical coherence tomography images; to the right are graphs depicting the thickness. The arrows point to the superior area of the NFL and indicate areas of difference due to AD. The normal has a superior NFL thickness of $104 \mu \mathrm{m}$ and the AD thickness is $58 \mu \mathrm{m}$. AD = Alzheimer disease; NFL = nerve fiber layer; TEMP = temporal; SUP = superior; NAS = nasal; INF = inferior. Images were acquired using a Stratus OCT (Carl Zeiss Meditec, Inc.)

Optical coherence tomography (OCT) is used for the management of diseases affecting the eye. It has the ability to measure the thickness of the nerve fiber layer (NFL) of the retina. OCT is similar to ultrasound, but utilizes light. Unlike ultrasound, there is no tissue contact. OCT measures structures less than $10 \mu \mathrm{m}$ scale. In a study that evaluated individuals with Alzheimer disease (AD) and control individuals, Danesh-Meyer and colleagues ${ }^{1}$ found a reduction in NFL in those with AD, but not control individuals. Parisi and colleagues ${ }^{2}$ also found significant reductions in the NFL of those with AD and this group included mild AD.

Denise A. Valenti, OD, FAAO, Boston, MA

Address correspondence and reprint requests to Dr. D.A. Valenti, Ophthalmology, Boston University, 715 Albany St., 9th fl., Boston, MA 02118; dvalenti@bu.edu

Supported by NIH Disability Supplement to R01 1AG15361, Mentored Research/Training: Changes in Optic Nerve Fiber Layer Secondary to Alzheimer's Disease.

Disclosure: The author reports no conflicts of interest.

The author thanks Thomas Laudate for his assistance with the acquisition of images in the Vision and Cognition Laboratory at Boston University.

\section{REFERENCES}

1. Danesh-Meyer HV, Birch H, Ku JY, Carroll S, Gamble G. Reduction of optic nerve fibers in patients with Alzheimer disease identified by laser imaging. Neurology 2006;67:1852-1854.

2. Parisi V, Restuccia R, Fattapposta F, Mina C, Bucci MG, Pierelli F. Morphological and functional retinal impairment in Alzheimer's disease patients. Clin Neurophysiol 2001;112:1860-1867. 


\title{
Neurology
}

\author{
Neuroimaging of retinal nerve fiber layer in AD using optical coherence tomography \\ Denise A. Valenti \\ Neurology 2007;69;1060 \\ DOI 10.1212/01.wnl.0000280584.64363.83
}

This information is current as of September 4, 2007

\begin{tabular}{|c|c|}
\hline $\begin{array}{l}\text { Updated Information \& } \\
\text { Services }\end{array}$ & $\begin{array}{l}\text { including high resolution figures, can be found at: } \\
\text { http://n.neurology.org/content/69/10/1060.full }\end{array}$ \\
\hline References & $\begin{array}{l}\text { This article cites } 2 \text { articles, } 1 \text { of which you can access for free at: } \\
\text { http://n.neurology.org/content/69/10/1060.full\#ref-list-1 }\end{array}$ \\
\hline Citations & $\begin{array}{l}\text { This article has been cited by } 2 \text { HighWire-hosted articles: } \\
\text { http://n.neurology.org/content/69/10/1060.full\#\#otherarticles }\end{array}$ \\
\hline Permissions \& Licensing & $\begin{array}{l}\text { Information about reproducing this article in parts (figures,tables) or in } \\
\text { its entirety can be found online at: } \\
\text { http://www.neurology.org/about/about_the_journal\#permissions }\end{array}$ \\
\hline Reprints & $\begin{array}{l}\text { Information about ordering reprints can be found online: } \\
\text { http://n.neurology.org/subscribers/advertise }\end{array}$ \\
\hline
\end{tabular}

Neurology ${ }^{\circledR}$ is the official journal of the American Academy of Neurology. Published continuously since 1951, it is now a weekly with 48 issues per year. Copyright . All rights reserved. Print ISSN: 0028-3878. Online ISSN: 1526-632X.

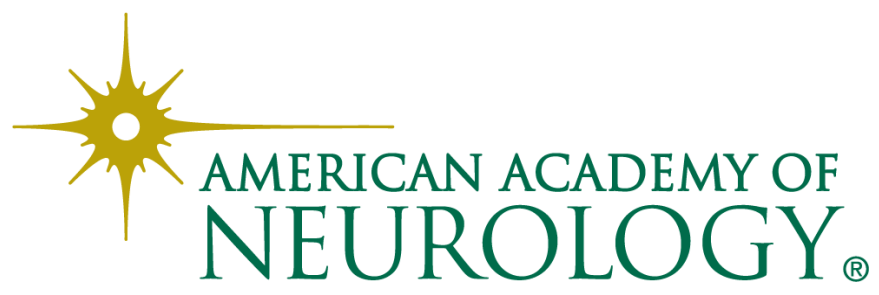

